\title{
First record of Thysanozoon brocchii (Platyhelminthes: Polycladida) from Indian waters
}

\author{
Reshma Pitale* and Deepak Apte
}

\begin{abstract}
This work reports the occurrence of Thysanozoon brocchii from the rocky intertidal coast of Ratnagiri and Dwarka, the West Coast of India, for the first time. Two morphotypes were found, the first morph has a buff brownish papillate dorsal surface, with few specimens having white spots. The second morph has light coloured papillae which form a distinct cross marking along the dorsal surface. The species possesses double male copulatory apparatus with seminal vesicle, prostatic vesicle and sclerotized stylet. This cosmopolitan species has previously been recorded from Italy and Mediterranean, Japan, South and West Africa, Florida, New Zealand, Brazil, and United Kingdom. Synonymized species and older descriptions have been compared to examine similarities and dissimilarities. Considering the existence of varied colour morphs of this species, a detailed comparative analysis of morphological characters, reproductive histology and molecular framework is recommended.
\end{abstract}

Keywords: Pseudocerotidae, Colour patterns, Intraspecific variations, Reproductive anatomy, Cosmopolitan, Maharashtra, Gujarat

\section{Introduction}

Polyclad flatworms are free living members of the phylum Platyhelminthes. These coral reef and rocky shore inhabitants are more diverse in the tropical environment (Prudhoe, 1985). Cryptic behavior, apparent specificity with food preference, aposematic colouration and mimicry with opisthobranch molluscs and fishes (Ang \& Newman 1998; Newman \& Canon, 2005) make them potentially significant in intertidal or reef ecology.

Members of the family Pseudocerotidae are peculiar for their brilliant colour patterns. However, colour variation is commonly seen forming species complex in their systematics. Perhaps such complexities arising in the taxonomy of these worms can be resolved by careful observations of external as well as reproductive anatomical features. Newman and Canon (1995) described three species of the genus Pseudoceros from the Indo-Pacific region showing remarkable similarity within external appearance. They, too, emphasized the significance of precise documentation of colour and patterns. Litvaitis,

* Correspondence: rd.pitale@bnhs.org

Bombay Natural History Society, Hornbill House, S.B. Singh Road, Mumbai, Maharashtra 400 001, India et al. (2010) tested the coloration pattern of Pseudoceros bicolor complex against molecular evidence and emerging complexities in the taxonomy of the same.

Grube (1840) described the genus Thysanozoon considering the papillate dorsal surface, unlike the rest of the Cotylean genera. Type species of the genus was Thysanozoon diesingii, which has later been synonymized for T. brocchii. This genus includes about 23 species worldwide (Tyler, 2013). Laidlaw (1902) reported Thysanozoon plehni from the Laccadive Island of India. However, this species has been reviewed and assigned to Acanthozoon plehni. After a gap of about a century, Apte and Pitale (2011) mentioned a member of this genus from Kavaratti, Lakshadweep Island, India. Later, Sreeraj and Raghunathan (2013) reported Thysanozoon nigropapilosum from South Andaman.

The present study reports Thysanozoon brocchii for the first time from the Indian shoreline. Apart from external morphology and reproductive anatomy, the study encompassed the review of characteristic features of some of the synonyms and a few previous descriptions, and their comparisons with the two different morphs presented herein. 


\section{Materials and methods}

Collection was carried out during the daytime low tide by handpicking the worm using a paint brush, within the littoral area of Ratnagiri (Mandvi $16.98758^{\circ} \mathrm{N} 73.27486^{\circ} \mathrm{E}$ ), Maharashtra state and Dwarka (22.240323 N 68.957424 E), Gujarat state, West Coast of India (Fig. 1). Presence of heterogeneous habitat is a common characteristic of both these shores, and pebbles, cobbles and rock pools of various sizes and depths are found at various zones. Luxuriant growth of algae and patches of coral-rubble were observed during surveys.

Photographs were taken in the wild as well as ex situ to record true colour and pattern. Animals were then fixed in $10 \%$ frozen buffered formalin and later stored in $70 \%$ ethanol for long term preservation (Quiroga et al., 2004). Studies on key anatomical features were carried out using a Stereo Microscope (Leica EZ4 D). The systematic classification system established by Faubel (1984) was followed. Longitudinal serial sections of the reproductive system (6 $\mu \mathrm{m})$ were obtained by specimen (Pclad-0044) embedding in paraplast and staining with hematoxilin and eosine. Remaining specimens are deposited in collections of the Bombay Natural History Society.
SYSTEMATICS.

Order POLYCLADIDA Lang, 1884

Suborder COTYLEA Lang, 1884

Family Pseudocerotidae Lang, 1884

Genus Thysanozoon Grube, 1840

Thysanozoon brocchii Risso, 1818

\section{Material examined}

Two specimens $(11.49 \mathrm{~mm} \times 8.32 \mathrm{~mm}$ and $11.30 \mathrm{~mm} \times$ $8 \mathrm{~mm}$, preserved) found under rock pebble at Mandavi, Ratnagiri, 9 May 2012 (BNHS_Pclad-0044) as 18 histological slides.

One specimen (10.2 $\mathrm{mm} \times 8.5 \mathrm{~mm}$ preserved) found under rock pebble within algae at Dwarka, Gujarat, 12 December 2012 (BNHS_Pclad-0080).

\section{Diagnosis}

Brown-buff to cream dorsal surface with yellowish brown to dark brown papillae cover, margin with pinkish tint; ends with white dotted line. Papillae from median longitudinal line are lighter thus distinct, transverse line of light coloured papillae about $1 / 3 \mathrm{rd}$ posterior to longitudinal length also present in single

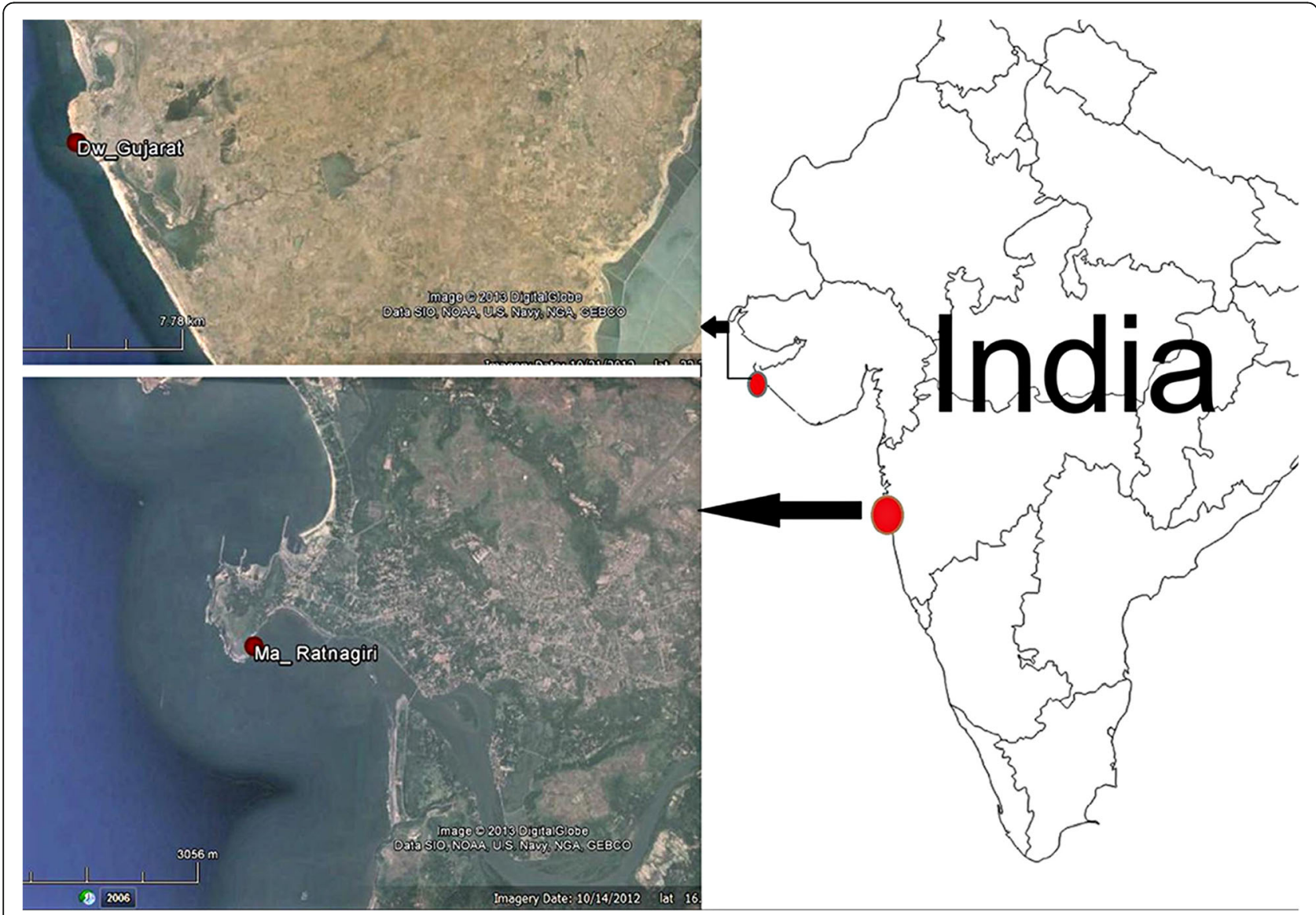

Fig. 1 Geographical distribution of Thysanozoon brocchii from Ratnagiri and Dwarka, West Coast of India. Courtesy: Google earth 
specimen (Pclad-0080); double male reproductive structures; elongated vagina.

\section{Description}

The first morph (BNHS-Pclad-0044) is broadly oval, oblong body and found slightly raised medially. Dorsal surface covered with papillae which are aggregated in median region, diminish in size, and become scarce towards margin and found absent a little above the margin. Papillae are approximately cylindrical $(0.3 \mathrm{~mm}-0.4 \mathrm{~mm})$, knob-like or even tapering in the same specimen.

Dorsal surface, ground colour is buff-brown-creamish with black median longitudinal stripe. Yellowish reticulation of intestinal branches observed prominently towards margin. Pinkish tint found towards periphery, and a dotted white line on the rim. Papillae are buff-brown to dark brown having grayish outline and some possess white spots around the tip. Papillae present over median longitudinal stripe are mostly distinct, tapering, and lack brown pigments. These papillae are creamish or whitish, possess white dots and run antero-posteriorly. Pseudotentacles are held erect; they are ear-like, creamish brown and with white tip. On the inner margin of each pseudotentacle, a fine black line that runs towards the median stripe can be observed. Cerebral eyespots (30-34) arranged in horseshoe-shaped cluster (size $0.27 \mathrm{~mm}$ ), present within the colourless area just posterior to the pseudotentacles (Fig. 2c). Pseudotentacular eyes are found distributed as four clusters dorsally and two clusters ventrally. Dorsal cluster bears about 40-45 eyespots whereas ventral cluster bears about 50-60 eyespots.

Another morph (BNHS-Pclad-0080) has creamish dorsal surface and yellowish reticulation noticed especially towards margin (Fig. 2b). Dotted white line delineates the margin. Brown coloured papillae are cylindrical, pointed, with white spots around the tip. Papillae present over
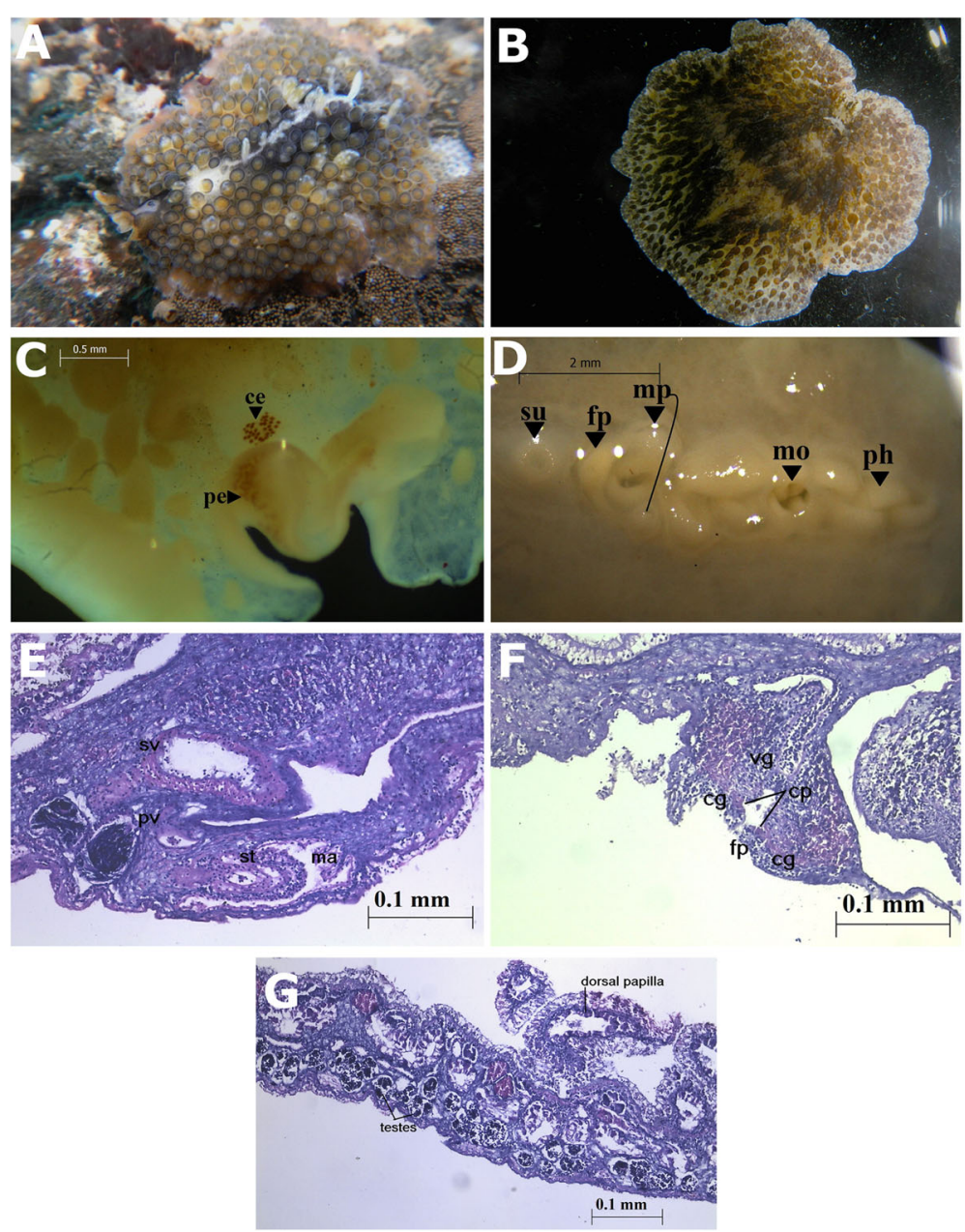

Fig. 2 Thysanozoon brocchii Risso, 1818: a (1st morph) under pebble within the rock pool (b) 2nd morph (c) anterior end with cerebral eyespots (ce), pseudotentacular eyespots (pe); (d) ventral surface showing pharynx (ph), Mouth (mo) male gonopore (mp), female gonopore (fp), sucker (su); (e) Sagittal section of male reproductive system with male antrum (ma), prostatic vesicle (pv), stylet (st); (f) female reproductive structure with vagina (vg), cement pouch (cp), cement gland (cg), Intestine (it); (g) ventral testes and dorsal papillae 
median longitudinal and transverse line are creamish, possess white spots and form a cross-like marking. Blackbrown pigments of the median stripe can be seen over anterior region and on the pseudotentacles.

The two morphs described above are similar in terms papillae arrangement, median lighter papillae and margin colouration. The papillae shape in second morph is cylindrical and white dots present over each papillae are more numerous than the first morph. Ground colour is creamish and papillae colour is darker and colour tone is more even in second morph as in the first one. Considering the distinctive colour pattern of second morph the single specimen has been kept intact and not been sectioned for histology.

Semi-transparent whitish ventral surface, with a mouth, opening medially within pharynx and about $3.01 \mathrm{~mm}$ distant from anterior margin (Fig. 2d). Pharynx is in the form of 4-5 simple and shallow folds and about $4.68 \mathrm{~mm}$ long. Two male gonopores are present immediately behind the pharynx, on either side of the median line and about $1.24 \mathrm{~mm}$ distant from each other. Medially placed, female gonopore is present $0.71 \mathrm{~mm}$ posterior to the male gonopore followed by sucker $(0.46 \mathrm{~mm}$ from $\mathrm{fp})$.

Double male copulatory system with numerous testes (0.02 $\mathrm{mm}$ to $0.04 \mathrm{~mm}$ in length) arranged in $2-3$ rows located ventrally. Seminal vesicle $(0.14 \mathrm{~mm} \times 0.064 \mathrm{~mm})$ is muscular, slightly oval, bent and pointed at its anterior end (Fig. 2e). Vas deference arranged laterally, visible through ventral side and runs posteriorly. Small and oval prostatic vesicle $(0.0435 \mathrm{~mm} \times 0.0342 \mathrm{~mm})$ found ventral to the seminal vesicle. Penis with stylet found further down to the seminal vesicle, probably contracted or bent during fixation, as it is visible only in the form of a rounded structure (Fig. 2e). Male atrium is shallow $(0.045 \mathrm{~mm})$.

Female reproductive system consists of ovaries which are found scattered dorsally. Female antrum is narrow, with minute lateral invagination for cement pouches. Vagina elongated backward $(0.2 \mathrm{~mm})$ and cement glands are seen spread around vagina (Fig. 2f).

\section{Taxonomic remarks}

In taxonomic study of pseudocerotidae, the genus Thysanozoon is difficult, probably due to the unavailability of enough details in the older literature. Body colour pattern, papillae shape, their colour and distribution are important features in the taxonomic study of this genus (Brusa et al., 2009). The specimens (BNHS_Pclad-0044 and 0080) somewhat fit with the original description of Risso, 1818 and specimens described later (Palombi, 1928; Pearse, 1938; Marcus and Marcus, 1968; Brusa et al., 2009 and Bahia et al., 2012, 2014) from different parts of the world.
About twenty species described earlier have later been synonymized for T. brocchii (Faubel, 1984). Table 1 gives the review of the characters noted from these synonyms.

Tergipes dicquemare, Planaria dicquemari and Thysanozoon dicquemaris although very poorly described, seems to be similar in terms of dorsal and ventral colour pattern. Planaria tuberculata, Planaria verrucosa are similar in terms of colour and pattern. Eolidiceros panormis and Thysanozoon diesingii are nearly identical due to possession of yellow and purple pigment on dorsal surface as well as the purple dash lines on the margin. The colour pattern of Eolidiceros brochii is slightly different from the other species due to possession of reddish-brown papillae and purple dots all over the dorsal surface. Four of the synonyms viz. E. panormis, T. diesingii, T. lagidium and T. fockei are found possessing purple pigmentation on dorsal surface. Transverse bands of lighter papillae forming a cross were observed within E. panormis, T. brochii var. cruciatum and T. lagidium. The remarks section of Table 1 elaborates the comments from the authors about the resemblance of their respective specimens, either with $T$. brocchii or previously described allied species. Diesing (1850) reports about Thysanozoon tuberculatum and synonymizes three previously known species viz. Planaria tuberculata, Thysanozoon dicquemaris and Planaria dicquemari. Planaria brocchi and Eolidiceros brocchi are synonymised for the species Thysanozoon brocchii and Eolidiceros panormus for Thysanozoon panormus respectively. Further, Diesing (1862) while separately mentioning the genus Thysanozoon, synonymizes species which are described earlier under the varied genera viz. Planariae spec. by Delle Chiaje, Stylochi spec. by Diesing Eolidiceri spec. by Quatrefages.

Table 2 gives an account of characters mentioned from some of the older descriptions of Thysanozoon brocchii. The descriptions by Quatrefage (1845) and Lang (1884) are unvarying and collected from type locality of the concerned species. Material obtained from Japan (Yeri and Kaburaki, 1916; Kato, 1944) was found resembling the above two descriptions, especially in terms of possessing purple pigment and papillae colour pattern. Palombi (1928) differs with Lang (1884), Quatrefage (1845), Yeri \& Kaburaki (1916), and Marcus and Marcus (1968) due to having exclusive brown dorsal pigment and ventral eyespot arrangements. Meanwhile, Pearse (1938) recorded the three morphs (pigmentation- brown, purple and intermediate) of the species from Crooked Island. Marcus and Marcus (1968) elaborated the reason for presence of broader female antrum in Marcus (1949) material of T. lagidium. They also discussed the external and internal anatomical, intraspecific variations within this species and finally merged T. lagidium with $T$. brocchii. Faubel (1984) while reviewing the polyclad systematics followed the same criteria. However, Prudhoe (1985) 


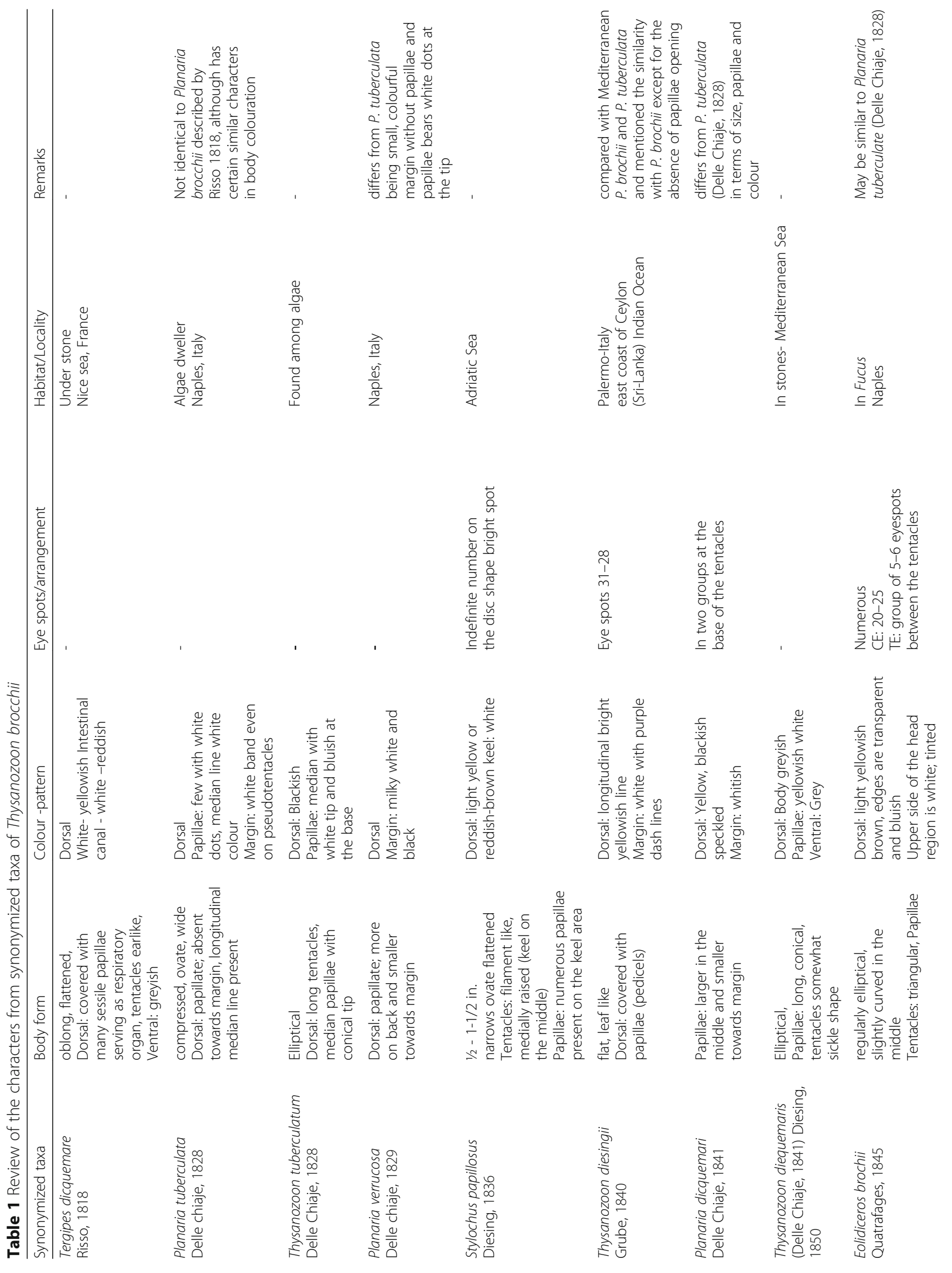



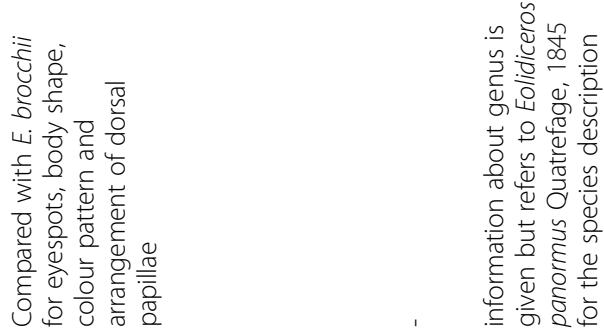

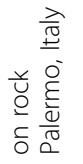

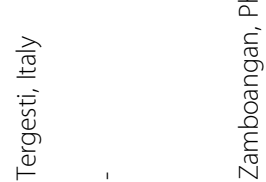

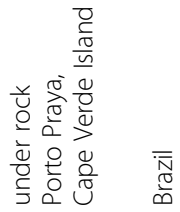

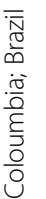
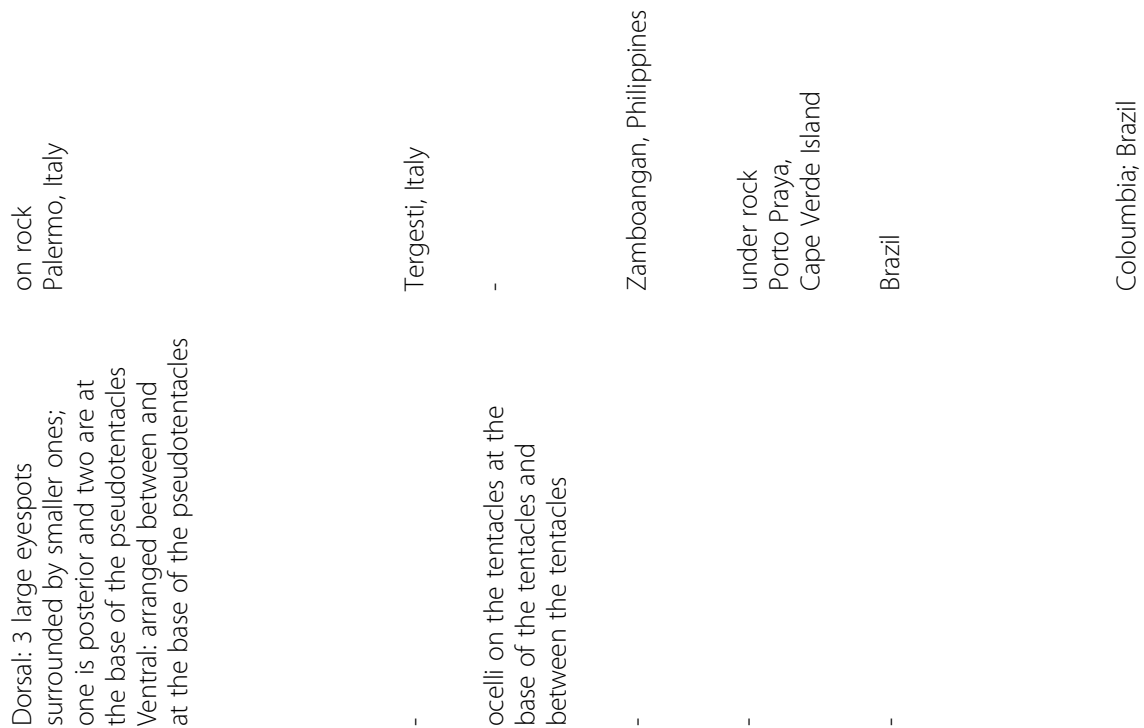


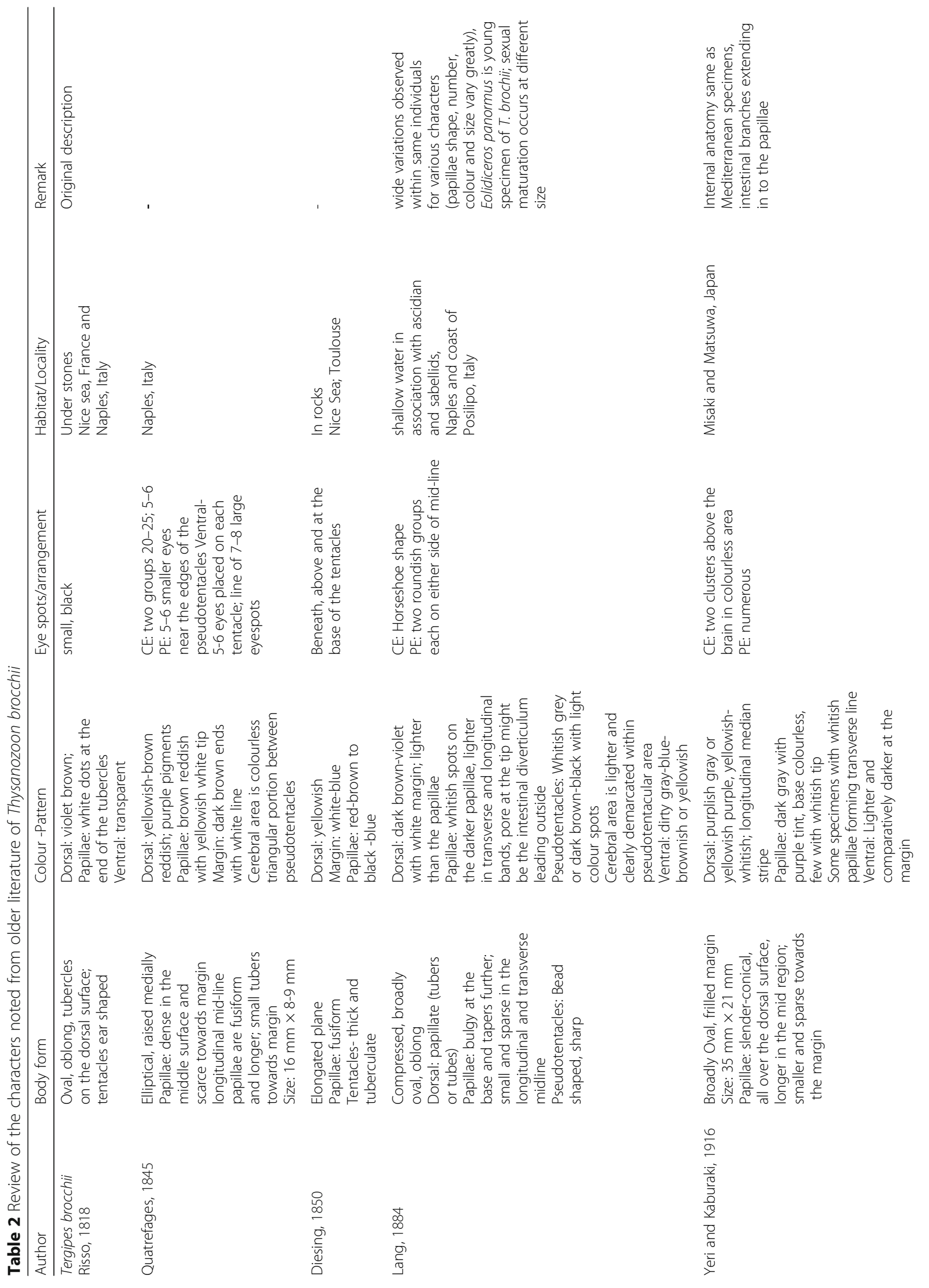




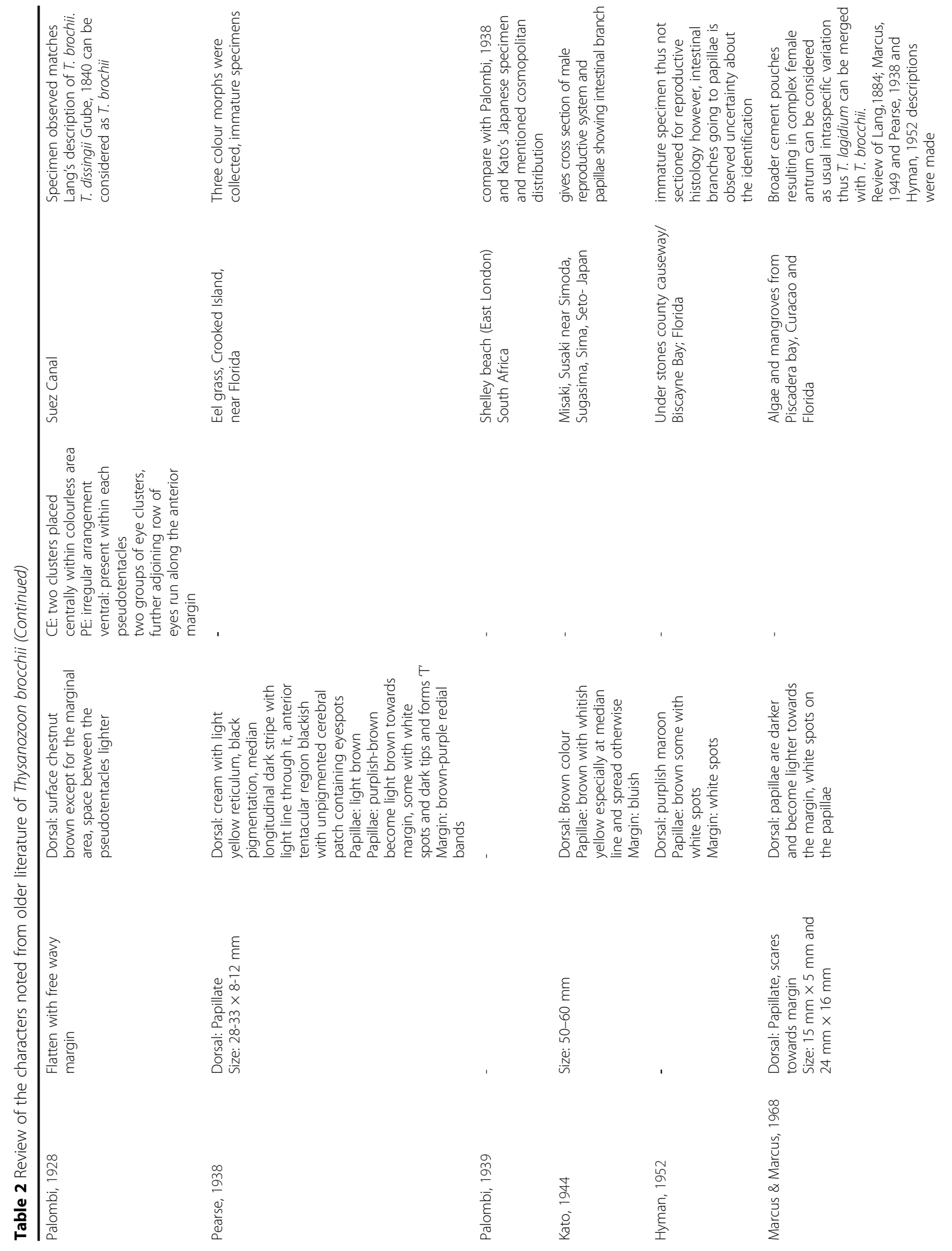




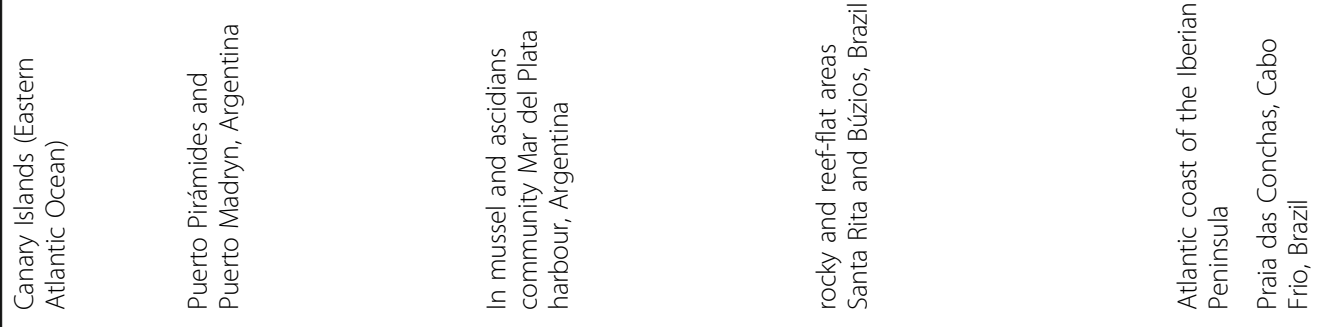

\begin{tabular}{|c|c|}
\hline 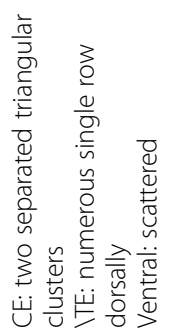 & 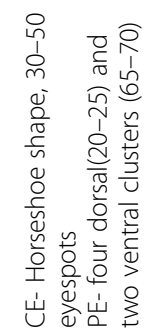 \\
\hline
\end{tabular}

\begin{tabular}{|c|c|c|c|c|c|}
\hline 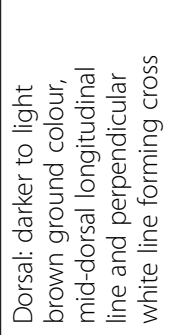 & 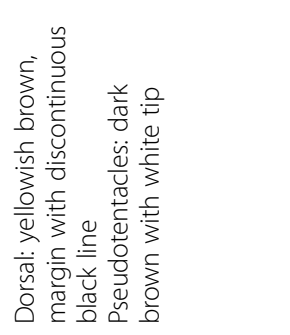 & 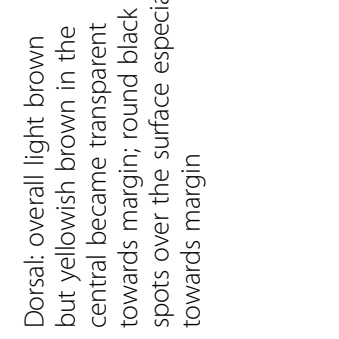 & 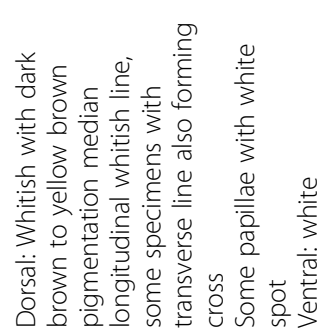 & 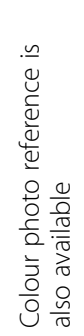 & 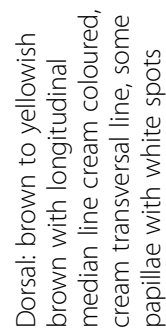 \\
\hline & 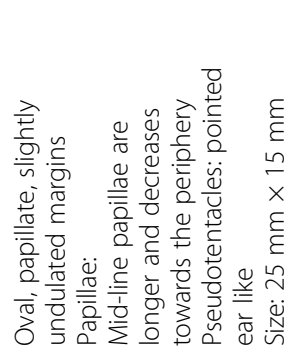 & 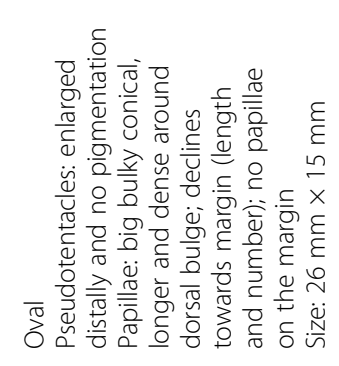 & 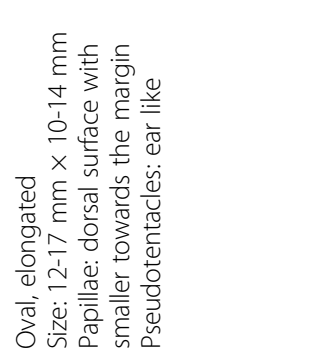 & 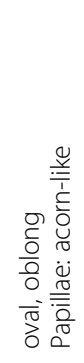 & 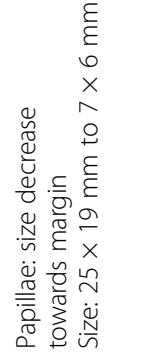 \\
\hline 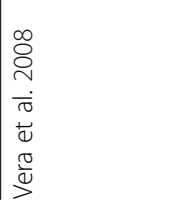 & 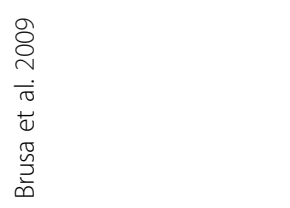 & 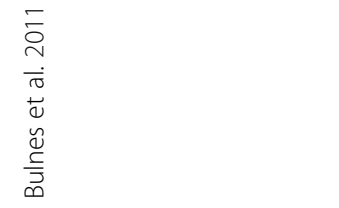 & 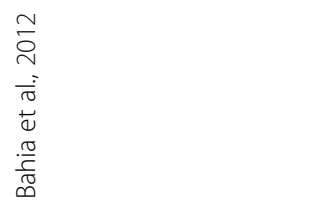 & 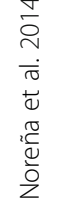 & 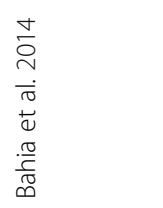 \\
\hline
\end{tabular}


considered T. lagidium as a separate species. Two recent findings (Brusa et al., 2009 \& Bahia et al., 2012, 2014) from Argentina and Brazil respectively show absence of purple pigments mentioned in most of the older records. Current specimens (First morph) found intermediate of all the older descriptions, but shows approximate resemblance with Bahia et al., 2012, 2014 in terms of colour-pattern and eyespots arrangement. Second morph shows close similarity with Pearse (1938) (brown morph) Quiroga et al., 2004 and Brusa et al., 2009.

Overall, compilation and comparison certainly represents the combinations of colour patterns exist between the T. brocchii species complex (Table 3). Perhaps these combinations are accountable for the current taxonomic confusion. Nonetheless, several currently synonymized species have also been synonymized previously and their progress (from genera - Tergipes, Eolidiceros or Planeolis) towards the genus Thysanozoon (after 1840) is clearly

Table 3 Colour variation on each part of the colour pattern observed in the literature cited

Major colour and pattern combinations observed

Dorsal ground colour

whitish; cream; light yellow; brown; light brown; grey; dark gray; blackish; dark purple; chestnut brown; white-yellowish; yellowish brown; yellow-greenish; yellowish-brownreddish; yellowish purple, reddish-brown; grayish-brown-purple; violet-brown; purplish gray; purplish maroon;

Ground colour-pattern

Speckled

Pigments

Reticulation

Median stripe

Black; brown

Round spots

Papillae colour

Purple; brown; dark brown to yellow brown

light yellow

dark

black

whitish; dark gray; yellowish-white; yellowpurple, reddish-brown; black-brown; brown reddish; black-blue; purplish-brown, brown; Bluish base

Papillae colour - pattern

\begin{tabular}{|c|c|}
\hline Dots & White; blackish purple \\
\hline Tip & White; yellowish white \\
\hline Base & colourless \\
\hline Tints & purple \\
\hline Margin Colour & $\begin{array}{l}\text { white; Milky white to black; white-purple; } \\
\text { white-blue; bluish; dark brown; brown- } \\
\text { purple; transparent }\end{array}$ \\
\hline \multicolumn{2}{|c|}{ Margin colour-pattern } \\
\hline Band & White; radial \\
\hline Dash & purple \\
\hline Speckled & brown \\
\hline Spots & white \\
\hline Line & discontinuous black \\
\hline
\end{tabular}

evident as one approaches from Risso (1818) to Marcus and Marcus (1968). But, several older descriptions are not even and do not cover all the criteria which can be commonly used to compare species within the complex. Faubel (1984) while revising polyclad systematics includes twenty such species as synonyms of T. brocchii. Prudhoe (1985) proposed the T. lagidium as different species based on the transfer line forming ' $\mathrm{T}$ ' shape colour pattern of papillae. However, with reference to the information presented in the Table1 few more species exist with similar character and not found stated by Prodhoe (1985). Thus, for a time being T. lagidium should be consider as the synonym for T. brocchii as mentioned by Faubel (1984).

Currently, this species is known from Naples, Italy (type locality), other parts of the Mediterranean, Algeria, Suez Canal (Palombi, 1928), South and West Africa, Florida, Brazil, Argentina, Borneo, Japan, Vietnam, New Zealand (Prudhoe, 1989) and with this report, extend to the Indian Coast.

\section{Discussion}

Comparative examinations clearly indicate and support the fact of existence of variable colour morphs of this species. Certainly, usual intraspecific variation and two or more species sharing similar colour patterns are two contended facts that exist, particularly in the pseudocerotid polyclads. Thus, the allocation of all presently noted morphs for $T$. brocchii is only convincing when external colour patterns, characters of reproductive anatomy and molecular framework reveal the similarity. In this context, revision of this species is urgently required. Perhaps fresh collection of specimens from the similar or adjacent places of previously described region can contribute to resolve mystery of colour patterns. Cladistical analysis using external characters and molecular data techniques are beneficial. Bulnes et al., 2011 raised important query about the cosmopolitan distribution and temperature as limiting factor in polyclad species distribution. Thus, ecological data inferring the habitat and food preference should be encouraged.

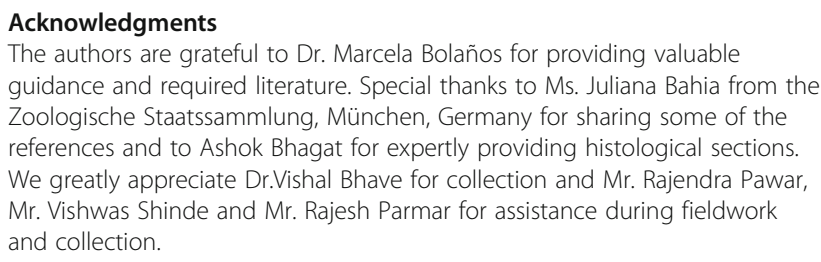

\section{Authors' contributions}

RP first collected, identified and reported species. RP drafted the manuscript. DA guided and provided funds required for the study and carried out final editing of the manuscript. Both authors read and approved the final manuscript.

\section{Competing interests}

The authors declare that they have no competing interests. 


\section{Publisher's Note}

Springer Nature remains neutral with regard to jurisdictional claims in published maps and institutional affiliations.

Received: 15 April 2016 Accepted: 6 February 2017

Published online: 28 July 2017

\section{References}

Ang HP, Newman LJ. Warning colouration in pseudocerotid flatworms (Platyhelminthes, Polycladida), a preliminary study. Hydrobiologia. 1998;383: 29-33.

Apte D, Pitale R. New records of Polyclad flatworms (Platyhelminthes: Turbellaria) from coral reefs of Lakshadweep Island, India. J Bombay Nat Hist Soc. 2011;108(2):109-13

Bahia J, Padula V, Delgado M. Five new records and morphological data of polyclad species (Platyhelminthes: Turbellaria) from Rio Grande do Norte, northeastern Brazil. Zootaxa. 2012;3170:31-44.

Bahia J, Padula V, Lavrado HP, Quiroga S. Taxonomy of Cotylea (Platyhelminthes: Polycladida) from Cabo Frio, southeastern Brazil, with the description of a new species. Zootaxa. 2014;3873(5):495-525.

Brusa F, Damborenea C, Quiroga S. First records of Pseudocerotidae (Platyhelminthes: Polycladida: Cotylea) from Patagonia, Argentina. Zootaxa. 2009;2283:51-9

Bulnes VN, Albano MJ, Obenat SM, Cazzaniga NJ. Three pseudocerotid (Platyhelminthes, Polycladida, Cotylea) species from the Argentinian coast. Zootaxa. 2011:2990:30-44

Delle CS. Descrizione e notomia degli animali invertebrati della Sicilia citeriore osservati vivi negli anni. Naples: Batteli \& Co.; 1841. p. 1-8.

Delle Chiaje S. (1822-1829) Memorie sulla storia e notomia degli animali senza vertebre dell regno di Napoli. Napoli 1822-1829. [the atlas with $109 \mathrm{pl}$. appeared 1822; the 4 vols of text appeared as Vol 2; 1828 Vol 3; $1830117-$ 214. Fratelli Fernand.

Diesing CM. Helminthologische Beiträge. Nova Acta Acad Leopoldina. 1836;18:316. Diesing C. M. (1850) Systema Helminthum. I. Vindobonae, 679.

Diesing K. Revision Der Turebellarien. IN COMMISSION BEI KARI, GEROLD'S SOHN, BÜCHHÄNDLER DER KAISERL. AKADEMIE DER WISSENSCHAFTEN. 1862:2:485-578.

Faubel A. The Polycladida, Turbellaria. Proposal and establishment of a new system. Part II. The Cotylea. Mitteilungen des Hamburgischenzoologischen Museums und Instituts. 1984;81:89-259.

Grube AE. (1840) Actinien, Echinodermen und Wuermer des adriatischen und Mittelmeers, nach eigenen Sammlungen beschreiben. Koenigsberg. 92.

Hyman LH. Further notes of the turbellarian fauna of the Atlantic Coast of the United States. Biol Bull. 1952;103:195-200.

Kato K. Polycladida of Japan. J Sigenkagaku Kenkyusyo I. 1944:257-318.

Laidlaw F. The marine Turbellaria, with an account of the anatomy of some species. Fauna Geology Maldive Laccadive Archipelagoes. 1902;1:282-312.

Laidlaw, F. (1906) On the marine fauna of the Cape Verde Islands, from collections made in 1904 by Mr C. Crossland. The polyclad Turbellaria. Proceedings of Zoological Society London, 705-719.

Lang A. Die Polycladen des Golfes von Neapel und der angrenzenden Meeresabschnitte. Eine Monographie. Fauna Flora des Golfesv. Neapel, Leipzig. 1884:11:1-688.

Litvaitis M, Bolaños M, Quiroga S. When names are wrong and colours deceive: unravelling the Pseudoceros Bicolor species complex (Turbellaria: Polycladida). J Nat Hist. 2010;44(13):829-45. doi:10.1080/00222930903537074.

Marcus E. Turbellaria brasileiros (7). Boletim da Faculdade de Filosofia, Ciências e Letras da Universidade de São Paulo Zoologia. 1949;14:7-155.

Marcus E, Marcus E. Polycladida from Curaçao and faunistically related regions. Stud Fauna Curaçao Caribb Isl. 1968;101:1-133.

Moseley HN. On Stylochus Pelagicus, an new species of pelagic planarian, with notes on other pelagic species, on the larval forms of Thysanozoon, and of a Gymnosomatous Pteropod. Mciroscopical J. 1877;17:23-32.

Newman $L$, Cannon LRG. Color pattern variation in tropical flatworm, Pseudoceros (Platyhelminthes: Polycladida) with description of three new species. Raffles Bull Zool. 1995:43:435-46.

Newman LJ, Cannon LRG. Fabulous flatworms: a guide to marine polyclads. Version 1. Canberra and Melbourne, Australia: ABRS and CSIRO Publishing CD-ROM; 2005
Noreña C, Marquina D, Pérez J, Almon B. First records of Cotylea (Polycladida Platyhelminthes) for the Atlantic coast of the Iberian peninsula. ZooKeys. 2014;404:1-22. doi:10.3897/zookeys.404.7122.

Palombi A. Report on the Turbellaria (Cambridge expedition to the Suez Canal, 1924). Transact Zool Soc London. 1928;22:579-632.

Palombi A. Turbellari del sud Africa. Secondo contributo. Arch Zool Ital. 1938:25:124-49.

Palombi A. Turbellaria del Sud Africa. Policladi di East London. Terzo contributo Arch zool Italiano. 1939:28:123-49.

Pearse A. Polyclads of the east coast of North America. Proc U S Nat Mus. 1938;86:67-98.

Prudhoe S. A monograph on Polyclad Turbellaria. Oxford: Oxford University Press; 1985. p. 259.

Prudhoe S. Polyclad turbellarians recorded from African waters. Bull $\mathrm{Br}$ MusnatHist (zool). 1989:55(1):47-96.

Quatrefages De A. Études sur les types inférieurs de l'embranchement des annelés: mémoire sur quelques planairées marines appartenant aux genres Tricelis (Ehr.), Polycelis (Ehr.), Prosthiostomum (Nob.), Proceros (Nob.), Eolidiceros (Nob.), et Stylochus (Ehr). Annales des Sciences Naturelles, (3) Zool. 1845:4:129-84.

Quiroga S, Bolaños M, Litvaitis M. A checklist of polyclad flatworms (Platyhelminthes: Polycladida) from the Caribbean coast of Colombia, South America. Zootaxa. 2004;633:1-12.

Risso A. Mémoire sur quelques Gastéropodes nouveaux Nudibranches et Tectibranches observés dans la mer de Nice. J Physique, Chimie, d'Hist natt et Arts. 1818:87:272-376.

Sreeraj C, Raghunathan C. Pseudocerotid polyclads (Platyhelminthes, Turbellaria, Polycladida) from Andaman and Nicobar Islands, India. Proc Int Acad Ecol Environ Sci. 2013;3(1):36-41.

Stimpson W. Prodromus descriptionis anumalium evertebratorum quea in Expeditione as Oceanum, Pacificum Septentrionalem a Republica Federata missa, Johanne Rodgers Duce, observavit et descripsit. Part I Turbellaria Dendrocoela. Proc Acad Natl Sci Phila. 1857:9:19-31.

Tyler S. (2013) Thysanozoon Grube, 1840. Accessed through: World Register of Marine Species at http://www.marinespecies.org/aphia.php?p=taxdetails\&id= 142242 on 2013-10-01.

Vera A, Moro L, Bacallado JJ, Hernández F. Contribución al conocimiento de la biodiversidad de políclados (Platyhelminthes, Turbellaria) em las Islas Canarias. Revista de la Academia Canaria de Ciencias. 2008;20(4):45-59.

Yeri M, Kaburaki T. (1916) Description of some Japenese polyclad turbellaria. J Coll Sci Tokyo Imperial Univ. XXXIX, 1-54.

\section{Submit your next manuscript to BioMed Central and we will help you at every step:}

- We accept pre-submission inquiries

- Our selector tool helps you to find the most relevant journal

- We provide round the clock customer support

- Convenient online submission

- Thorough peer review

- Inclusion in PubMed and all major indexing services

- Maximum visibility for your research

Submit your manuscript at www.biomedcentral.com/submit 